\title{
モード連成による旋盤の一次びびり振動の発生機構について*
}

\author{
太田博*1, 鬼頭昌士*2, 半田毅*3
}

\section{A Study on Primary Chatter Caused by Mode Coupling of Machine Tool Structure}

\author{
Hiroshi OTA*4, Masashi KITO and Tsuyoshi HANDA \\ ${ }^{* 4}$ Emeritus Professor, Nagoya University, \\ 1212 Musashizuka, Nagakute-cho, Aichi-gun, Aichi, 480-1121 Japan
}

\begin{abstract}
This study began to compare experiments with analysis of mode coupling of primary chatters in lathe. The movement of the workpiece traces an elliptical locus, however this becomes a circular locus near the stability limit. Either positive or negative of the traced direction in the elliptical locus has no relationship to the occurrence of chatter. When the major axis of the elliptical locus is exists in the quadrants 2 and 4, energy flows from the lathe spindle to the workpiece, and the vibration system becomes unstable. From the experimental data it can be seen that unstable vibration occurs when the major axis of the elliptical locus is exists in the quadrants 2 and 4 , thus corroborating the theoretical analysis.
\end{abstract}

Key Words : Lathe Cutting, Vibration of Workpiece, Vibratory System of Two Degrees of Freedom, Torque Applied to Lathe Spindle

\section{1. 緒 言}

工作機械におけるびびり振動は，強制振動源がある ために起こる強制びびり振動と，自励的に生じる自励 びびり振動 ${ }^{(1) \sim(5)}$ の 2 種類に分けられる.

これまでの研究によれば，自励ひびり振動の発生機 構には主として動的切削力の速度成分 ${ }^{(1)}{ }^{(2)}$ ，モード 連成 (1) (2)，再生効果 ${ }^{(3)}{ }^{(4)}{ }^{(5)}$ の三つがある.これらの 発生機構のうちモード連成については, 被削材の岡性 の方向差により被削材が楕円軌道を描いて振動し，切 削力によりエネルギーの流入が起こるとして説明され ている(1).

本論文では，旋盤の被削材に発生する一次自励ひび り振動について，被削材を剛性と減衰に方向差のある 2 自由度系と仮定し運動方程式 (4) (5) を立て, 切削 力と, 被削材の変位による復元力とが働くことに注目 し，エネルギーが旋盤主軸から流入すると考え，モ一

* 原稿受付 2006 年 6 月 30 日.

*1 正員, 名誉員, 名古屋大学名誉教授 (更 480-1121 愛知県愛知 郡長久手町武蔵塚 1212).

*2 アイシン・エイ・ダブリュ(株) (\$ 444-1164 安城市藤井町 高根 10).

*3 正員, 愛知工科大学工学部 (必443-0047 蒲郡市西迫町馬乗 50-2).

E-mail : handa-t@aut.ac.jp
ド連成による自励びびり振動の発生条件 (わ) (8) につい て考察した. また，この理論解析の妥当性を実験によ り確認した.

\section{2. 被削材の振動系}

モード連成は振動特性に方向差のある 2 自由度以上 の振動系で発生する. 本論文では，被削材と主軸を含

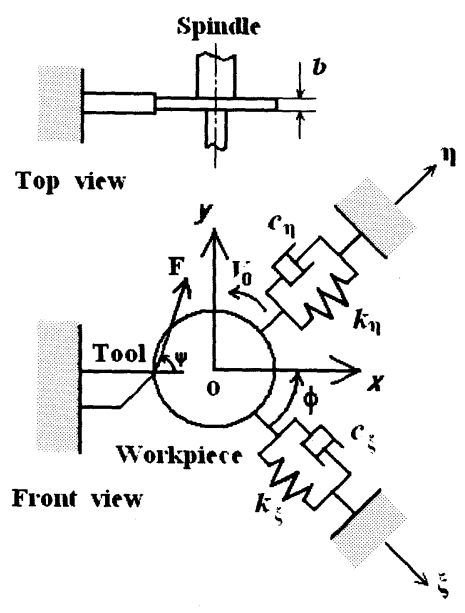

Fig.1 Vibratory system of workpiece 
めた系を剛性と減衰に方向差のある図 1 に示すような 2 自由度振動系と仮定することにする. また，工具の 岡性は被削材の岡性に比べ十分に大きいとして工具の 振動を無視し, 被削材のみが振動するものと仮定する.

\section{3. 被削材の運動方程式}

一般には図 1 に示寸基準座標からなる直交座標系 $O-\xi \eta$ と, 水平軸，鉛直軸加なる直交座標系 $O-x y$ とは互いに一致せず, 角度 $\phi=\angle \xi O x$ をなす. よって 切削合力 $F$ が作用するときの句に関する運動方程式 と切削力 $F_{\xi}, F_{\eta}$ は次式 (1), (2), (3)のようになる.

$$
\begin{aligned}
& \left.\begin{array}{l}
m \ddot{\xi}+c_{\xi} \dot{\xi}+k_{\xi} \xi=F_{\xi} \\
\ddot{\eta}+c_{\eta} \dot{\eta}+k_{\eta} \eta=F_{\eta}
\end{array}\right\} \\
& F_{\xi}=F_{x} \cos \phi-F_{y} \sin \phi=F \cos (\psi+\phi) \\
& F_{\ddot{\eta}}=F_{x} \sin \phi+F_{y} \cos \phi=F \sin (\psi+\phi)
\end{aligned}
$$

ただし $\psi$ は切削合力 $F$ の働く方向を, 水平軸 $x$ から測 った角である.

本論文ではモード連成に主眼をおくため, 切削力は 被削材の切り込み深さに比例する(動的切削力の時間 遅れ，切削速度に対する右下がり効果の両方を無視す る) と仮定する. よって切削力は,

$$
\left.\begin{array}{l}
F_{x}=-b f_{x} x \quad, \quad F_{y}=-b f_{y} x \\
F=-b f x
\end{array}\right\}
$$

と表される. 上式で $f=\sqrt{f_{x}^{2}+f_{y}^{2}}$ ，また $b$ は切削幅 である. $x$ は $\xi, \eta を$ 使って

$$
x=\xi \cos \phi+\eta \sin \phi
$$

と変換されるから，式（4），（5）を，式（2）， （3）に代入すれば, 式（1）は式（6）となる.

$$
\left.\begin{array}{rl}
m \ddot{\xi}+c_{\xi} \dot{\xi}+k_{\xi} \xi= & -b f \cos \phi \cos (\psi+\phi) \cdot \xi \\
& -b f \sin \phi \cos (\psi+\phi) \cdot \eta \\
m \ddot{\eta}+c_{\eta} \dot{\eta}+k_{\eta} \eta= & -b f \cos \phi \sin (\psi+\phi) \cdot \xi \\
& -b f \sin \phi \sin (\psi+\phi) \cdot \eta
\end{array}\right\}
$$

\section{4. 安定限界線図}

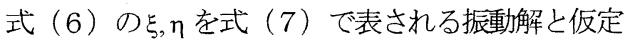
し，式（6）に代入すれば，振幅 $C, D$ に関する次のよ うな連立方程式（8）が得られる.

$$
\left.\begin{array}{l}
\xi(t)=C e^{s t}, \quad \eta(t)=D e^{s t} \\
G_{\xi \xi} C+G_{\xi \eta} D=0 \\
G_{\eta \xi} C+G_{\eta \eta} D=0
\end{array}\right\}
$$

$C=0, D=0$ 以外の解が存在するためには $C, D$ の係数 からなる行列式が 0 でなければならないから,

$$
G_{\xi \xi} G_{\eta \eta}-G_{\xi \eta} G_{\eta \xi}=0
$$

が成り立つ. 式（9）をsに関して展開すると, 次の 特性方程式（10）が得られる.

$$
\left.\begin{array}{c}
f(s)=s^{4}+T s^{3}+U s^{2}+V s+W=0 \\
T=\frac{1}{m}\left(c_{\xi}+c_{\eta}\right) \\
U=\frac{1}{m}\left(k_{\xi}+k_{\eta}+b f \cos \psi+\frac{c_{\xi} c_{\eta}}{m}\right) \\
V=\frac{1}{m^{2}}\left[c_{\xi} k_{\eta}+c_{\eta} k_{\xi}+b f\left\{c_{\xi} \sin (\psi+\phi) \sin \phi\right.\right. \\
\left.\left.+c_{\eta} \cos (\psi+\phi) \cos \phi\right\}\right] \\
W=\frac{1}{m^{2}}\left[k_{\xi} k_{\eta}+b f\left\{k_{\xi} \sin (\psi+\phi) \sin \phi\right.\right. \\
\left.\left.+k_{\eta} \cos (\psi+\phi) \cos \phi\right\}\right]
\end{array}\right\}
$$

式 $\left(\begin{array}{ll}1 & 0\end{array}\right)$ の Routh - Hurwitz の安定判別式 ${ }^{(6)}$ が零,

$$
R=T U V-V^{2}-T^{2} W=0
$$

のとき特性根 $\mathrm{s}$ は安定限界となる（純虚数）。また式

（1２）を変形することにより安定限界での切削幅 $b_{\lim }$ を与える条件式（1 3) が得られる.

$$
b_{\lim }=\frac{A_{2}+\sqrt{A_{3}}}{A_{1}}
$$

ここで, $A_{1}, A_{2}, A_{3}$ は次式 (14) で示される. 式 （1３）の条件式に表 1 の值 ${ }^{5}$ ) 代入して求めた安 定限界線図を図 2 に示寸。 


$$
\begin{aligned}
A_{1}=m f\{ & 4 c_{\xi} c_{\eta}+\left(c_{\xi}+c_{\eta}\right)^{2} \cos 2 \psi \\
& \left.-\left(c_{\xi}-c_{\eta}\right)^{2} \cos 2(\psi+2 \phi)\right\}
\end{aligned}
$$$$
A_{2}=4\left[-m\left(c_{\xi}+c_{\eta}\right)\left(c_{\eta} k_{\xi}+c_{\xi} k_{\eta}\right) \cos \psi-c_{\xi} c_{\eta}\left(c_{\xi}+c_{\eta}\right)\right.
$$$$
\times\left\{c_{\eta} \cos (\psi+\phi) \cos \phi-c_{\xi} \sin \phi \sin (\psi+\phi)\right\}
$$$$
+m\left(c_{\eta}^{2} k_{\xi}+c_{\xi}^{2} k_{\eta}\right) \cos \psi
$$$$
-c_{\xi} c_{\eta} m\left\{k_{\xi} \cos \phi \cos (\psi+\phi)+k_{\eta} \sin \phi \sin (\psi+\phi)\right\}
$$$$
\left.+3 c_{\xi} c_{\eta} m\left\{k_{\eta} \cos \phi \cos (\psi+\phi)+k_{\xi} \sin \phi \sin (\psi+\phi)\right\}\right]
$$

$$
\begin{aligned}
A_{3}= & 4 c_{\xi}^{2} c_{\eta}^{2}\left\{\left(c_{\xi}+c_{\eta}\right)^{2} \cos \psi-\left(c_{\xi}^{2}-c_{\eta}^{2}\right) \cos (\psi+2 \phi)\right. \\
& \left.+4 m\left(k_{\xi}-k_{\eta}\right) \cos (\psi+2 \phi)\right\}^{2} \\
& -8 c_{\xi} c_{\eta} m\left\{\left(c_{\xi}+c_{\eta}\right)\left(c_{\xi} k_{\eta}+c_{\eta} k_{\xi}\right)+\left(k_{\xi}-k_{\eta}\right)^{2} m\right\} \\
& \times\left\{4 c_{\xi} c_{\eta}+\left(c_{\xi}+c_{\eta}\right)^{2} \cos 2 \phi-\left(c_{\xi}-c_{\eta}\right)^{2} \cos 2(\psi+2 \phi)\right\}
\end{aligned}
$$

\begin{tabular}{|c|c|c|c|}
\hline $\begin{array}{l}\text { Root mean square value of } \\
\text { natural frequencies }\end{array}$ & $p / 2 \pi$ & $\mathrm{Hz}$ & 208 \\
\hline \multirow{2}{*}{ Spring constant } & $k_{\xi}$ & $\mathrm{M} \mathrm{N} / \mathrm{m}$ & 9.2 \\
\hline & $k_{\eta}$ & M N/hn & 10.8 \\
\hline \multirow{2}{*}{ Damping coefficient } & $c_{\xi}$ & Nshin & 613.1 \\
\hline & $c_{\eta}$ & $\mathrm{Ns} / \mathrm{m}$ & 841.2 \\
\hline Equiralent mass & $m$ & $\mathrm{~kg}$ & 5.85 \\
\hline $\begin{array}{l}\text { Angle of two } \\
\text { coordlnates system }\end{array}$ & $\phi$ & degree & 137 \\
\hline Specific tluust force & $f_{x}$ & GN/m $n^{2}$ & 0.61 \\
\hline Specifle cutting force & $f_{Y}$ & $\mathrm{GN} / \mathrm{m}^{2}$ & 1.42 \\
\hline
\end{tabular}

Table 1 Vibratory characteristics of workpiece ${ }^{(5)}$

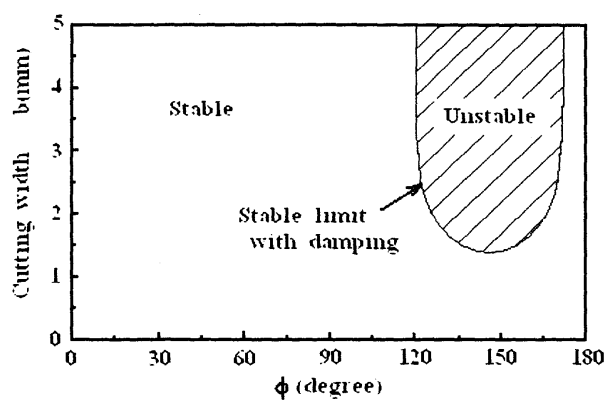

Fig2 Critical limit of stability

\section{5. 振動特性について}

図2 の安定限界線図付近の被削材の振動の特性を考 察するため特性方程式（10）の根の一つを $s=\alpha+i \beta$ とおき, 式 (8) 加ら次式 (1 5) 〜 (1 7) を得る.

$$
\begin{gathered}
\frac{D}{C}=p_{0}+i q_{0} \\
p_{0}=-\frac{m\left(\alpha^{2}-\beta^{2}\right)+c_{\xi} \alpha+k_{\xi}+b f \cos (\psi+\phi) \cos \phi}{b f \cos (\psi+\phi) \sin \phi} \\
\ldots \ldots \ldots \ldots \ldots \cdots) \\
q_{0}=-\frac{2 m \alpha \beta+c_{\xi} \beta}{b f \cos (\psi+\phi) \sin \phi}
\end{gathered}
$$

$\xi, \eta$ の振幅比 $\kappa$ と位相差 $\delta$ は次式で与えられる.

$$
\begin{aligned}
& \kappa=\sqrt{p_{0}^{2}+q_{0}^{2}} \\
& \delta=\tan ^{-1} \frac{q_{0}}{p_{0}}
\end{aligned}
$$

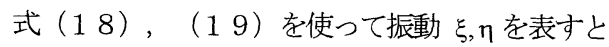

$$
\left.\begin{array}{l}
\xi(t)=C e^{\alpha t} e^{i \beta t}=E \cos \beta t \\
\eta(t)=\kappa C e^{\alpha t} e^{i(\beta t+\delta)}=\kappa E \sin (\beta t+\delta)
\end{array}\right\}
$$

とおくことができる. 被削材の描く式（20）の棈円 軌道は $\delta>0$ なら時計回り, $\delta<0$ なら反時計回りであ る. 式（19）で表される位相差は $\delta=0^{\circ} \sim 18$ $0^{\circ}$ であり，振動軌跡は常に時計回りである. このモ デルで仮定した振動系には特性方程式の根が共役複素 数の形で 2 組あることからも分かるとおり，二つの振 動様式が存在する.

本論文では，振動の理論解析をするにあたつて二つ の振動様式について，それぞれ根の実部 $\alpha$ をプロット したところ，片方の $\alpha$ が必ずもう片方の $\alpha$ よりも大き いことがわかった， $\alpha$ は振動の増幅や减衰を特徴づけ るものであるため, 特にびびり振動が発生する $\alpha>0$ となる解について振動特性の理論解析を行うことにし た. 式（2 1) において $E$ を一定值と仮定することに より，式（20）は次式（2 2) となる.

$$
\kappa^{2} \xi^{2}-2 \kappa \xi \eta \cos \delta+\eta^{2}-\kappa^{2} E^{2} \sin ^{2} \delta=0
$$

式（22）を行列で表し, 


$$
\begin{aligned}
& F(x)={ }^{t} x H x+2^{t} h x+j \\
& H=\left[\begin{array}{cc}
\kappa^{2} & -\kappa \cos \delta \\
-\kappa \cos \delta & 1
\end{array}\right] \\
& x=\left[\begin{array}{l}
\xi \\
\eta
\end{array}\right], \quad h=\left[\begin{array}{l}
0 \\
0
\end{array}\right]
\end{aligned}
$$

ここで, ${ }^{t} x$ は, $x$ の転置を示す.ささらに,

$$
{ }^{t} T H T=D \quad \text { (対角行列) }
$$

となる直交行列 $T$ と 2 次列ベクトル $x_{0}$ を用いて直交 変換と平行移動を組み合水せた直交座標変換,

$$
\begin{aligned}
& x=T y+x_{0} \\
& y=\left[\begin{array}{c}
\xi^{\prime} \\
\eta^{\prime}
\end{array}\right], \quad x_{0}=\left[\begin{array}{c}
x_{01} \\
x_{02}
\end{array}\right]
\end{aligned}
$$

を行い次式を得る.

$$
\begin{aligned}
& \lambda_{1} \xi^{\prime 2}+\lambda_{2} \eta^{\prime 2}-E^{2} \kappa^{2} \sin ^{2} \delta=0 \\
& \lambda_{1}=\frac{\kappa^{2}+1 \pm \sqrt{\left(\kappa^{2}+1\right)^{2}-4 \kappa^{2} \sin ^{2} \delta}}{2} \\
& \lambda_{2}
\end{aligned}
$$

式（2９）は棈円の式であり，被削材の振動軌跡は 棈円になることがわかる．棈円の形状については振幅 比 $\kappa$ と位相差 $\delta$ によ得られる棈円の短径と長径の比 を求めればわかる. 短径/長径の值は次式 $(3 \quad 1)$ で 表され，これを図3に示す。

$$
\begin{aligned}
\frac{r_{\min }}{r_{\max }} & =\sqrt{\frac{\min \left(\lambda_{1}, \lambda_{2}\right)}{\max \left(\lambda_{1}, \lambda_{2}\right)}} \\
& =\frac{\kappa^{2}+1 \pm \sqrt{\left(\kappa^{2}+1\right)^{2}-4 \kappa^{2} \sin ^{2} \delta}}{2 \kappa|\sin \delta|}
\end{aligned}
$$

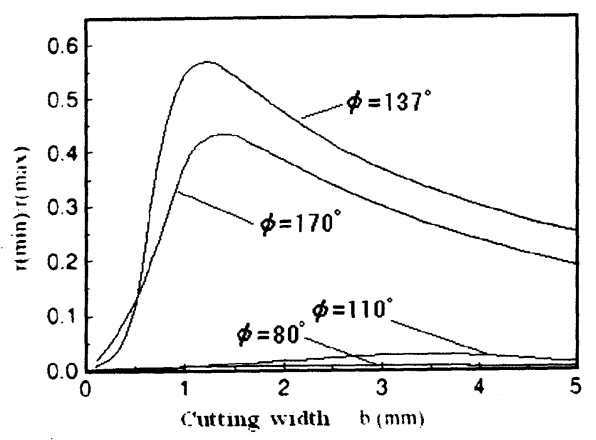

Fig 3 Minor axis/major axis
さらに楕円形状について詳しく調べるため, 図4に 示寸ように楕円の長径の主軸の向き $\theta$ について考える.

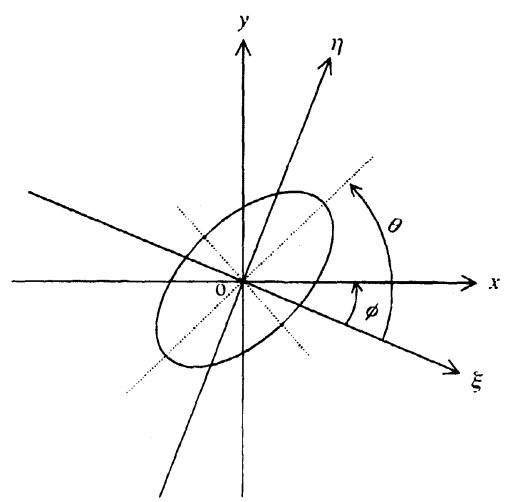

Fig 4 The direction of major axis of ellipse $\theta$

式（2 7）において $T$ は回転行列で,

$$
\left.\begin{array}{l}
T=\left[\begin{array}{l}
T_{11} T_{12} \\
T_{21} T_{22}
\end{array}\right] \\
T_{11}=T_{22}=-\frac{2 \kappa \cos \delta}{\sqrt{4 \kappa^{2} \cos ^{2} \delta+\left(-1+\kappa^{2}+\sqrt{Q}\right)^{2}}} \\
T_{12}=-T_{21}=-\frac{2 \kappa \cos \delta}{\sqrt{4 \kappa^{2} \cos ^{2} \delta+\left(-1+\kappa^{2}-\sqrt{Q}\right)^{2}}}
\end{array}\right\}
$$

である. したがって,

$$
T_{11}=\cos \theta
$$

と置くことにより，棈円の長径の主軸の方向 $\theta$ を知る ことができる.これを図5に示す。

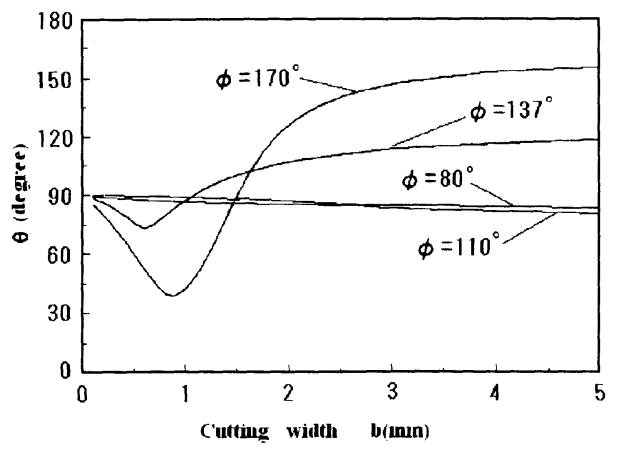

Fig 5 Direction of major axis of ellipse $\theta$ 
次に被削材の振動軌跡について考察してみる ${ }^{(7)}{ }^{(8)}$. まず楕円の軌跡は，常に時計回りの運動をする，従つ て位相差反によって安定, 不安定を論じることはでき ない!

次に楕円形状であるが，図 2 と図 3 からわかるよう に, 不安定領域の現れる剛性の方向 $\phi$ 以外では, 短径 /長径の值はほぼ零であり, 振動軌跡は往復直線運動

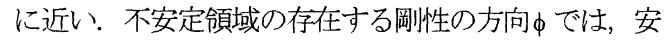
定限界付近で棈円軌跡は最も円形に近づき，その後ま た直線状になっていくことがわかる.

また棈円の長径の主軸の向き $\theta$ につても図 5 から わかるように，不安定領域の現れない剛性方向 $\phi$ では

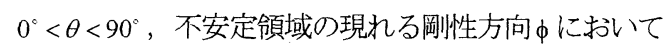
は, 安定領域で $0^{\circ}<\theta<90^{\circ}$, 不安定領域で $90^{\circ}<\theta<180^{\circ}$ である.

\section{6. 復元力()(8)}

被削材の微小変位に対する復元力について考える. 被削材のばね定数を $\xi$ 方向に $k_{\xi}=k-\Delta k, \eta$ 方向に $k_{\eta}=k+\Delta k$ とする. 座標系 $O-\xi \eta$ に対して, 点 $S(\xi, \eta)$ の復元力 $F^{-}$は $\xi, \eta$ 方向のばね定数が異なるため, 原 点 $O$ 方向を向かない. 復元力 $F^{-}$の $\xi, \eta$ 成分は,

$$
\left.\begin{array}{l}
F_{\xi}^{\prime}=-(k-\Delta k) \xi \\
F_{\eta}^{\prime}=-(k+\Delta k) \eta
\end{array}\right\}
$$

である. 復元力 $F^{\prime}$ の OS 成分 $F_{1}^{\prime}, O S$ と直角方向の成 分 $F_{2}^{\prime}$ は変位を $r=\sqrt{\xi^{2}+\eta^{2}}$ と置くと, 式 $(36)$ より

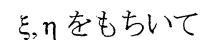

$$
\begin{aligned}
& F_{1}^{\prime}=-\frac{k r^{2}-\Delta k\left(\xi^{2}-\eta^{2}\right)}{r} \\
& F_{2}^{\prime}=\frac{-2 \Delta k(\xi \eta)}{r}
\end{aligned}
$$

となる. 旋回力 $F_{2}^{\prime}$ の反力 $-F_{2}^{\prime}$ は旋盤主軸にモーメン トを生じるが，軸の角速度を一定值 $\omega$ に保つためには， このモーメントとつりあうトルク

$$
T_{r}^{\prime}=F_{2}^{\prime} r=-2 \Delta k(\xi \eta)
$$

を旋盤主軸に加えてやらなければならない，点 $S$ を表 わす複素数 $\zeta=\xi+i \eta$ を用いると式（39）は

$$
T_{r}^{\prime}=-\Delta k \operatorname{Im}\left[\zeta^{2}\right]
$$

と表される.ここで被削材振動系に加えられるエネル ギーは単位時間あたり

$$
E=\omega T_{r}^{\prime}
$$

で表されるが，角速度 $\omega$ は一定值であるから， $T_{r}^{\prime} の$ 正負がそのまま被削材振動系のエネルギーの増加・減 少に対応する. したがって，被削材振動系のエネルギ 一を考えるには， $T_{r}^{\prime}$ の正負を考えればよい，図6に示

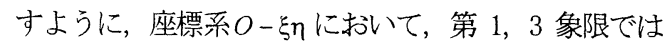
つねに $T_{r}^{\prime}<0$ ，第 $2 ， 4$ 象限ではつねに $T_{r}^{\prime}>0$ となる. もし点 $S(\xi, \eta)$ が第 2,4 象限により長い時間だけ存在 すれば，旋盤主軸からエネルギーが補給されるため, 被削材の振動は不安定となる. 従つて, $\xi, \eta$ 軸が $T_{r}^{\prime}$ の 正負の境界線となる.いま, とを

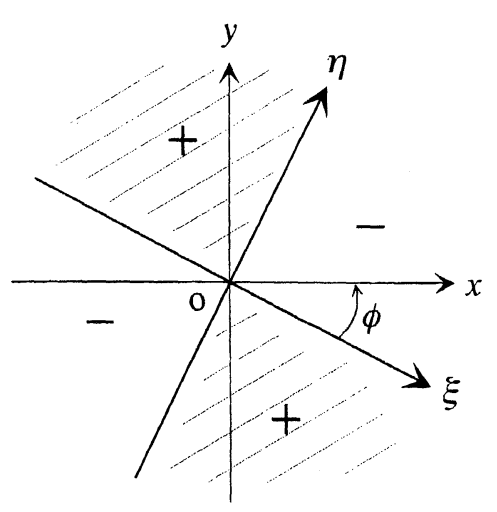

Fig6 Plus and minus zones of torque $T_{r}^{\prime}$

$$
\zeta=A e^{i p t}+B e^{-i p t}
$$

と仮定する. 式 (42) の で反時計方向に回転するべクトル（第 1 項）と，大き さ $|B|$, 角速度 $-p$ で時計方向に回転するべクトル（第

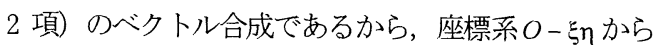
みた振動解は長径 $|A|+|B|$, 短径 $|A|-|B|$ の楕円軌跡を 描く．楕円の長径の主軸は，複素振幅 $A, B$ のなす角 の 2 等分線之一致することもわかる. 旋盤主軸のトル ク $T_{r}^{\prime}$ を計算すると, 式 $(40) ，(42)$ より

$$
T_{r}^{\prime}=-\Delta k \operatorname{Im}\left[A^{2} e^{2 i p t}+2 A B+B^{2} e^{-2 i p t}\right]
$$

となる ${ }^{(7)}{ }^{(8)}$. 式 (4 3) の右辺の [ ] 内の第 1 項と第 3 項の虚部は時間 $t$ とともに周期的に変動する のみで，その時間平均值は0であるからら，これらの項 は旋盤主軸からのエネルギーの出入りにはまったく関 係がない，第 2 項の虚部は $T_{r}^{\prime}$ の正負に影響する. $A B$ の虚部 $\operatorname{Im}[A B]<0$ は $T_{r}^{\prime}>0$ に, $\operatorname{Im}[A B]>0$ は $T_{r}^{\prime}<0$ にそ れぞれ対応する. $T_{r}^{\prime}>0$ となるのは $\operatorname{Im}[A B]<0$ のとき であり，これは複素振幅 $A, B$ のなす角の二等分線が複 素平面(図6)の第 $2 ， 4$ 象限にあるときである.した 
がって，被削材の描く棈円軌跡の主軸が第 $2 ， 4$ 象限 にあるときに動的不安定振動が発生する ${ }^{(7) ，(8) . ~}$

位相差反については式 (42) において, $|A|$ と $|B|$ の大小関係によって決まるものであり, $|A|>|B|$ であ れば軌跡は反時計方向に回り $\delta<0,|A|<|B|$ であれば 軌跡は時計方向に回り $\delta>0$ となる. したがって, 位 相差ठについては, 被削材のびびり振動の発生に関し て意味を持つものでないことがわかる. 今回の条件に おいてはすべての領域において, $|A|<|B|$ であったた め，軌跡は時計回りであり， $\delta>0$ となったのである. 図 5 において, 楕円の主軸の向きは, 不安定領域では $90^{\circ}<\theta<180^{\circ}$ であり第 2 象限にある.

また棈円の形状については，短径／長径の值が大き いということは，楕円が円に近いということであり， このとき点 $S$ は, 第 $1 \rightarrow$ 第 $4 \rightarrow$ 第 $3 \rightarrow$ 第 2 象限と移動 するが，それぞれの象限にあるときの時間がほぼ同じ となり, エネルギーの流入と散逸の差がなく, 振動は 収束も発散もしない安定限界となる. 逆に短径/長径 の值が小さければ，棈円の主軸の向きによっては，第 1 , 第 3 象限にある時間が第 2 , 第 4 象限にある時間 よりも長くなり, エネルギーの散逸量がエネルギーの 流入量を上回り，振動は収束する．あるいは，第 2 , 第 4 象限にある時間が第 1 , 第 3 象限にある時間より も長くなれば，エネルギーの流入量が散逸量を上回り， 振動は発散することになる.

\section{7. 切削力}

切削力により働くモーメントに対して旋盤主軸に加 えなければならないトルクは, 次式 (44) となる.

$$
T_{r}=-x F_{y}+y F_{x}=-b f_{x} x\left(y-\frac{f_{y}}{f_{x}} x\right)
$$

前節 6 の復元力と同じように, 図 7 の原点 $O$ を通 る切削力 $F$ の直線が $T_{\mathrm{r}}$ の正負の境界線となる. した がって, 切削力の方向 $\psi$ も, 被削材の振動の安定, 不 安定を決定する要因となることがわかる.

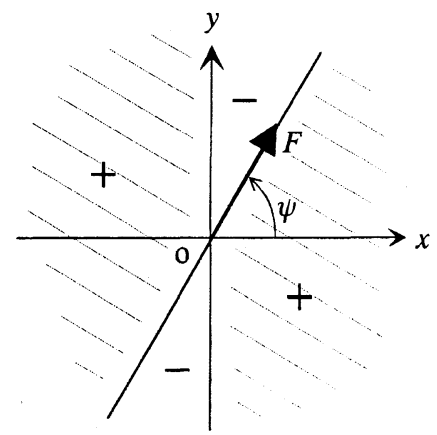

Fig 7 Phus and minus zones of torque $T_{\mathrm{r}}$

\section{8. 実験結果}

実験にはオークマ (株) 製のL S 4 $50 \times 800$ 型 旋盤を使用した. 切削中に被削材の振動特性および定 常切削中の切削条件が変化しないよう, 切削工具に突 つ切りバイト (イゲタロイ $43-4$, 非鉄金属用超硬 合金H 2，すくい角 $6^{\circ}$ ，逃げ角 $6^{\circ}$ ）を用いて乾燥 状態で横切り切削を行った. また実験では, 被削材の 水平変位 $\boldsymbol{x}$ と鉛直変位 $y$ をセンサで, 切削力の背分力 $F_{x}$ と主分力 $F_{y}$ を切削動力計で，旋盤主軸の毎分回転 数をロータリエンコーダでそれぞれ測定した ${ }^{(5)}$.

被削材の振動系は、振動モデルで仮定したように, 旋盤の主軸，駆動軸，支持軸など被削材とともに变位 する全ての部分が含まれる．旋盤の主軸側の振動系は 複雑で, 特にチャックは有限個のつめによって被削材 を保持しているため, 静止座標系からみると周期的に 被削材の剛性が変化する. それで駆動軸一の被削材の 取り付けはチャックを用いずにボルト8本で行い，さ らに旋盤主軸側の岡性の被削材岡性への寄与率を下げ るため, 駆動軸と支持軸のばね定数の比は被削材の位 置でほぼ 1：20 とされており, 被削材の剛性がほと んど支持軸および心押台の剛性に依存するような構造 である. 被削材 (旋盤主軸, 結合部玉軸受, 偏平支持 軸と心押台）の構造を図 8 に示す。 また, 駆動軸は回 転し, 支持軸は固定となっているため, 被削材のばね 定数が非線形とならないように複列自動調心型軸受 \# 2205 を年して両者は結合されている. 被削材の材 料としては切削力の変動が小さい黄銅板（JIS-C2801P, 外径 $160 \mathrm{~mm}$ ，幅 $5 \mathrm{~mm}$ ）を用いた.

得られた電気信号 $\left(x, y, F_{x}, F_{y}\right)$ は, A-D 変 換をしてサンプリング時間 $0.6 \mathrm{~ms}$ でデジタル值として パーソナルコンピュータに転送し，あらかじめ求めた 換算係数をかけることにより变位，切削力が得られる.

実験条件については, 旋盤の構造上から剛性の方向 性は変らないので, $\phi=137^{\circ}$ で, 切削幅 $\mathrm{b}$ のみを変え る実験を行った.

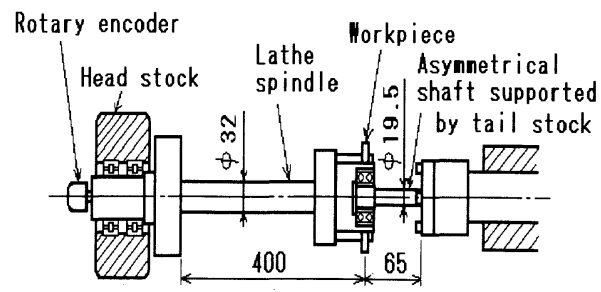

Fig8 Lathe spindle, asymmetrical shaft supported by tail stock 
切削幅 $3.85,2.95,2.00 \mathrm{~mm}$ (不安定領域) と

切削幅 $1.50,1.00 \mathrm{~mm}$ (安定領域)

との五つの切削幅の実験を行った. 得られた楕円の短 径/長径の值を図 9 に, 棈円の長径主軸の方向 $\theta$ を図 10 に示す.

図 9 の切削条件による棈円の短径と長径の比の変化 を見ると，やはり安定限界に一番近いところで最も大 きくなっており，他の条件と比べて円形に近い楕円軌 道を描くことがわかる. また図 10 は切削幅 b が楕 円の主軸の向き $\theta$ に与える影響を示したが，安定領域 では第 1 象限，不安定領域では第 2 象限にあることが わかる.

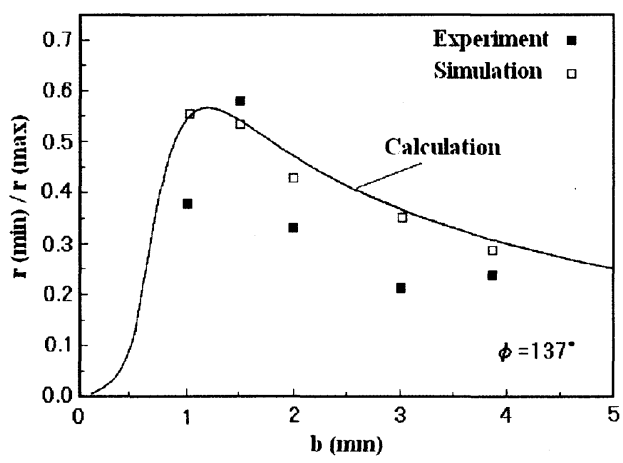

Fig9 Mmor axis/major axis

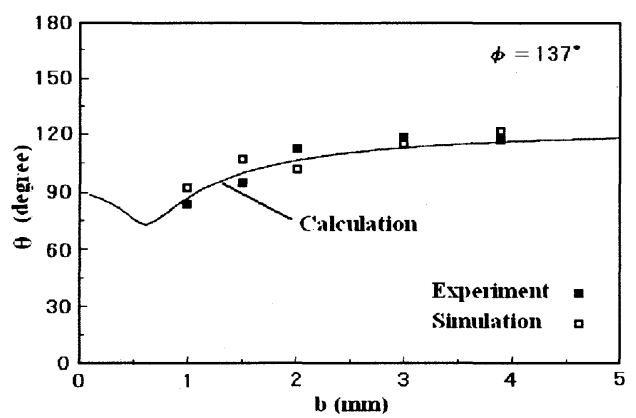

Fig 10 Direction of major axis of ellipse $\theta$

実験結果(ロ印)は解析結果(実線)とほぼ同じであり, 解析結果の妥当性を示している. なお, 運動方程式

（6）の数值計算解を定常振動の式（3 1)，（3

5)・に代入した結果を口印で図 9 と図 10 に示したが 解析結果 (実線) とよく一致している.

\section{9. まとめ}

本研究は，モード連成を考慮した解析モデルを仮定 し振動の特性, エネルギーの供給について, 理論と実 験の両面から考察した。 モード連成による一次びびり
振動の安定限界線図と振動特性を，エネルギーの流入 源が旋盤主軸であると考え，以下の結論を得た。

（1）被削材の運動は棈円軌道を描くが，安定限界付 近では円形軌道に近い.

（2）棈円軌道の回転方向，すなわち位相差 $\delta$ の正負 は被削材の振動の安定，不安定に無関係である.

（3）楕円軌道の長径の主軸が第 2，4 象限にあると きに，旋盤主軸から被削材にエネルギーが流入するた め動的不安定振動が発生する.

（4）切削力の働く方向 $\psi$ も被削材の振動の安定，不 安定を決定する要因となる.

（5）実験データにおいて，動的不安定振動の発生領 域においては楕円軌道の長径の主軸が第 2，4 象限に あり理論解析と一致する.

\section{文献}

(1) Kato, S. and Marui, E., Some Considerations on Prevention of Chatter Vibration in Boring Operation, Transactions of JSME, Vol.33, No.254 (1967), pp.1685-1692.

(2) Ota, H. and Kono, K., Chatter Vibrations of Machine Tool or Work with Directional Stiffness Inequality, Transactions of JSME, Vol.38, No.314 (1972),pp.2543-2557.

(3) Ota, H. and Kono, K., On Chatter Vibrations of Machine Tool or Work due to Regenerative Effect and Time Lag, Transactions of ASME, Joumal of Engineering for Incustry, Vol.96, No.4 (1974), pp.1337-1346.

(4) Ota, H. et al., On the Occurrence of Regenerative Chatter Vibrations, Transactions of JSME, Series C, Vol.52, No.480 (1986), pp.2278-2286.

(5) Ota, H. et al., Regenerative Chatter Vibrations of Tur ning Workpiece (1st Report, Two Degrees of Freedom and its Stability Criterion), Transactions of JSME, Series $C$. Vol.54, No.504 (1988), pp.1953-1960.

(6) Yamamoto, T. and Ota, H., Dynamics of Machines (Revised Edition in Japanese) (1986), p. 180. Asakura.

(7) Ota, H. and Mizutani. K., Influence of Unequal Pedestal Stiffness on the Instability Regions of a Rotating Asymmetrical Shaft (3rd Report, Mechanism for Occurrence of Two Types of Unstable Vibrations ), Transactions of JSME, Series C, Vol.46, No.408 (1980), pp.873-882.

(8) Ota, H. and Mizutani, K., On the Shaft End Torque and the Unstable Vibrations of an Asymmetrical Shaft Carrying an Asymmetrical Rotor, Transactions of JSME, Series $C$, Vol.48, No.426 (1982), pp.155-165. 